This is an Open Access article, distributed under the terms of the Creative Commons Attribution licence (http://creativecommons.org/licenses/by/4.0/), which permits unrestricted re-use, distribution, and reproduction in any medium, provided the original work is properly cited.

\title{
Frontiers and Mobilities: The Frontiers of the Roman Empire and Europe
}

\author{
Richard Hingley \\ Department of Archaeology, Durbam University, UK
}

This article addresses questions relating to the 'Frontiers of the Roman Empire World Heritage Site' and seeks to introduce into this initiative some concepts derived from recent writings on contemporary mobilities and bordering, exploring the possibility of creating greater engagement between the two academic fields of 'border studies' and 'Roman Frontier Studies'. By examining the relationship between the Roman Frontiers initiative and the European Union's stated aims of integration and the dissolution of borders, it argues in favour of crossing intellectual borders between the study of the present and the past to promote the value of the Roman frontiers as a means of reflecting on contemporary problems facing Europe. This article considers the potential roles of Roman Frontier Studies in this debate by emphasizing frontiers as places of encounter and transformation.

Keywords: borders, frontiers, encounter, mobilities, Roman Empire, European Union, World Heritage

\section{INTRODUCTION}

A new focus on mobilities and migrations is developing in archaeology across the world (van Dommelen, 2014). ${ }^{1}$ Archaeologists, particularly in Britain, have focused on human mobility within the Roman Empire, using a series of newly-developed scientific techniques that offer new understandings (Eckardt, 2010; Eckardt et al., 2014; Eckardt \& Müldner, 2016; Martiniano et al., 2016; Redfern et al., 2016). The Roman past provides a particularly significant parallel to the modern world with the large-scale movements of people across the

\footnotetext{
1 'Migration' involves the movement of people across physical space (Jansen et al., 2015), while 'mobilities' is a far broader term that 'encompasses both the largescale movement of people, objects, capital, and information across the contemporary world, as well as the more local processes of daily transportation, movement through public space and the travel of material things within everyday life' (Hannam et al., 2006: 1).
}

Empire and the apparent success of the imperial administration in assimilating people from disparate backgrounds into a settled society (Hingley, 2005; Versluys, 2014). This material is sometimes used directly to reflect on issues of mobility and migration in the contemporary UK (e.g. Hingley, 2010; Tolia Kelly, 2010; Eckardt \& Müldner, 2016: 215-16). The discipline of Roman Frontier Studies is also focusing increasing attention on the function of Roman frontier works and the transformative character of the frontier on the populations within and beyond the border zones (Hingley, in press; see also Wells, 2013; Jankovic et al., 2014; Roymans et al., 2016; González Sánchez \& Guglielmi, in press),

\footnotetext{
${ }^{2}$ I will not draw a clear distinction between frontiers and borders. Usually frontiers are more formal, substantial, and physical, while borders may be virtual and conceptual.
} 
although research on the geographical origins of those living on the Roman frontiers remains fairly rare.

The 'Frontiers of the Roman Empire World Heritage Site' (FREWHS) initiative is casting an interesting light on issues of migration. This transnational initiative has been developed since the early 2000s by Roman frontier specialists and heritage managers (Figure 1), involving UNESCO State Parties from western, central, and eastern Europe (Breeze \& Jilek, 2008; Sommer, 2015). This article has been written as a review of this theme and as a response to the decision of the UK government, and a small majority of the British public, during the summer of 2016 to withdraw from the European Union (EU). This move toward British separation from Europe seems to be symptomatic of the growing global trend in the West to define migration as problematic, which is leading to the development of policies that control and monitor migrants in the 'most stringent ways' (Jansen et al., 2015: 1).
The manner in which the FREWHS initiative has defined the value of the Roman frontiers will be explored by drawing on the EU's two central concepts, integration and the dissolution of borders. The character of the FREWHS will be addressed as a series of venues for encounter and transformation rather than as measures of (former) national or colonial division (see Cooper \& Rumford, 2013: 114). These materials will be used to reflect on the trends toward nationalistic and divisive rhetoric in Europe, drawing on the prominence of the FREWHS to argue the value of heritage as a means of promoting inclusive messages that link into the interconnectedness of the people of Europe and the Mediterranean region. The role of the Roman frontiers as the borders of an intercontinental military dictatorship makes the World Heritage Site potentially particularly potent as a parallel and source of contemplation over concerns about contemporary border building and mobilities.

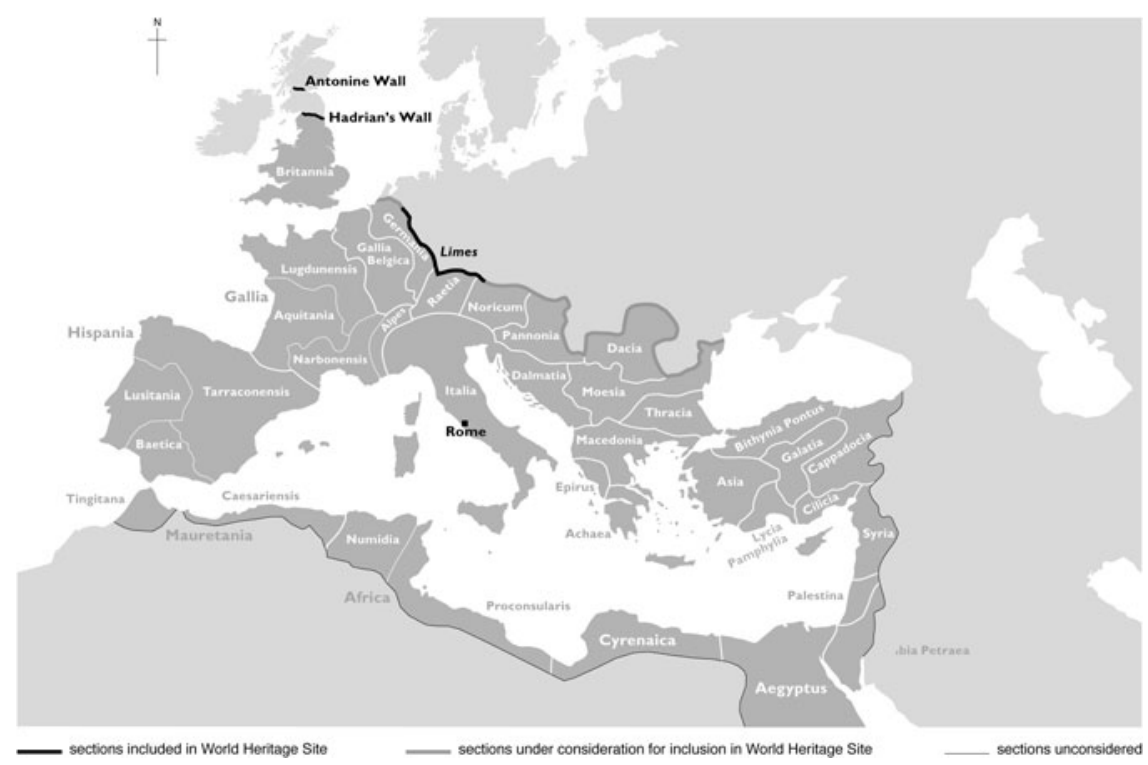

Figure 1. The frontiers of the Roman Empire and the Frontiers of the Roman Empire World Heritage Site (drawn by Christina Unwin). 


\section{Roman Frontier Studies and World Heritage Status}

First proposed during the early 2000s, the FREWHS has drawn in heritage professionals, educationalists, public agencies, and organizations, including UNESCO and the EU (Breeze \& Jilek, 2008; Mills, 2013). Many accounts of the Roman frontier works describe their physical form and their variable characters in different parts of the frontier zone (including Breeze et al., 2005; Klose \& Nünnerich-Asmus, 2005; Breeze, 2011; Moschek, 2011). These Roman frontier installations include: substantial linear fortifications across isthmuses (Hadrian's Wall and the Antonine Wall); systems of forts, roads, and ramparts that supported a river frontier (the limes along the Rhine and Danube); and complex landscapes of forts, roads, and ramparts in less well-defined frontier regions (North Africa and the Middle East; Breeze, 2011).

The FREWHS initiative was built upon the lengthy history of research into these physical remains (Breeze et al., 2005: 44; Breeze, 2008). Much of the initial archaeological work on Roman frontiers was undertaken in Germany, Austria, and Britain, where these relict physical works began to be uncovered during the nineteenth century (Breeze, 2011: 9-10; Moschek, 2011). Research has been carried out in other parts of Europe, although in North Africa and the Middle East this has been undertaken largely by European and American archaeologists (Mattingly et al., 2013: 44-47). Notable exceptions to this European and American focus are the scholarly studies in Israel that reflect longterm issues of national security (Isaac, 2000: 1-3; Gambash, 2015). This research has found a focus through the Congress of Roman Frontier Studies, which was established in 1949 and to date has met on twenty-three occasions at various locations in the frontier lands of the former Roman Empire (Birley, 2002). Large-scale surveying and mapping have been accompanied by excavation and fieldwork to uncover the location, sequence, character, and regional variability of the physical remains of Roman frontiers and their individual elements (Breeze, 2011: 9-12). Extensive research since the 1970s has also examined the military and civil populations of the Roman frontiers and the movement of peoples and artefacts both into and out of the Roman Empire across its frontiers (e.g. Bloemers, 1989; the 'thematic session II on Romans and natives' in Maxfield \& Dobson, 1991; Haffner \& von Schnurbein, 1996; Wells, 2013; Jankovic et al., 2014).

\section{The 'Frontiers of the Roman Empire World Heritage Site' Initiative and EUROPEAN IDENTITIES}

The FREWHS initiative involves significant co-operation between archaeologists and heritage managers in a number of European State Parties and also has the support of UNESCO (Breeze et al., 2005: 20; Breeze \& Jilek, 2008: 5). Following extensive discussion at the European Archaeological Association, Culture 2000 funding was obtained from the $\mathrm{EU}$ in 2005 to co-ordinate the management and interpretation of the Roman frontiers, communicating shared values to create an agenda for international co-operation (Breeze \& Jilek, 2008). To understand this initiative, it is important to consider the history of the World Heritage Site policy. The United Nations and UNESCO were formed in the aftermath of World War II to support internationalization, promote peace, and to encourage international co-operation and cultural respect. The 'Convention concerning the protection of Cultural and Natural World Heritage' was adopted by the General Conference of 
UNESCO in 1972 to promote this agenda (Askew, 2010: 20-23; Long \& Labadi, 2010: 5-6).

Despite UNESCO's excellent intention to recognize and protect important cultural and natural heritage resources, problems with World Heritage policies have subsequently emerged. World Heritage Sites have sometimes been used by State Parties to emphasize the ancestry and status of a particular people or territory (see Herzfeld, 2008: 146). Marc Askew (2010: 20-22) has made use of specific examples, including the Preah Vihear temple close to the border of Cambodia and Thailand, to outline the idea of the World Heritage List as a 'status-conferring artefact' in the competition for dominance between states. $\mathrm{He}$ has argued that, in some cases, the nomination process has been used for domestic agendas of cultural hegemony and state nationalism. Heritage resources often cross state boundaries and, therefore, are potentially difficult to inscribe and manage. As a response to such concerns, certain states have joined together to develop particular 'transnational World Heritage Site' nominations that span international boundaries and that promote international co-operation to communicate universal values.

UNESCO's 'World Heritage Centre' currently (October 2016) lists 1052 'properties' or individual World Heritage Sites (UNESCO, 2016), of which the FREWHS is one. It also forms one of thirty-four transnational World Heritage Sites (UNESCO, 2016; see Brough \& Scott, 2014: 116-17). The long-term ambition is to create a truly transnational FREWHS that encompasses all Roman frontier works across Europe, North Africa and the eastern Mediterranean. When the project was initiated, Hadrian's Wall was already inscribed, having been added to the World Heritage List in 1987. The limes along the Rhine and
Danube in Germany was nominated in 2004 and approved the following year. In 2008 the Antonine Wall in Scotland was added to the List. The current focus is on the nomination of the river frontiers along the Lower Rhine and eight additional Danubian states that contain the surviving Roman remains (Sommer, 2015: 920-21). Austria, Slovakia, Hungary, Croatia, and Serbia are currently co-operating over the nomination of their Roman frontier works (Zsolt, 2008: 74-75). The European focus of the FREWHS initiative reflects recent political changes. Following the collapse of their communist regimes, many central and eastern European countries joined the EU between 2004 and 2013, including Hungary, Slovakia, and Croatia (European Union, 2016). ${ }^{3}$

The concept of Europe is highly complex and draws on entangled historical roots and models, of which ideas deriving from Classical Rome comprise just one part (e.g. Graves-Brown et al., 1996; Biebuych \& Rumford, 2012: 5-6). Imperial Rome has, however, constituted a powerful element in the European psyche since Classical times. Classical writings and the physical remains of Classical cultures have been used to frame cultural, political, and military strategies, especially since the rediscovery of Greek and Roman texts and material remains during the Renaissance (Hingley, 2001; Morley, 2010; Witcher, 2015). The ethnic origins of European peoples are far more complex than a simple claim to former unity under the Roman Empire might suggest, and different regions of Europe have had recourse to a wide variety of supposedly ancestral populations from the ancient and more recent past (see Geary, 2002; Eder, 2006; Zielonka, 2006; Hsu, 2010). Imperial

\footnotetext{
${ }^{3}$ Negotiations are currently underway to consider the membership of Serbia and a number of other countries within an expanded EU.
} 
Rome has nevertheless been fundamental to the modern European project.

Although the Roman Empire has not always been represented in an entirely positive light, the organization now known as the EU has drawn deeply on this concept since the foundation of the European Economic Community by a Treaty signed in the city of Rome in 1957. This choice of city was not random, since, as one commentator on the FREWHS has recently argued, Rome stands for the principles of 'peace, governance, law and order, and above all unity' that lie at the core of the EU's purpose (Figel, 2008: 1). The original treaty stressed the idea of integration and the dissolution of borders (European Commission, 1957). European policy has continued to stress the free movement of people within Europe and has also worked to create ethical measures to control migration from outside the EU's borders.

The documents produced through the FREWHS initiative emphasize strongly these aims of integration and the dissolution of borders. Among the initiative's publications intended to communicate the ideas behind this transnational monument is the booklet Frontiers of the Roman Empire (Breeze et al., 2005), with text in English, German, French, and Arabic. A statement on the 'common cultural heritage of the Roman Empire' states the aims of the initiative:

'Roman frontiers are part of a common beritage of the countries circling the Mediterranean Sea. Successive generations have built on that heritage and modified it, thus helping to create our modern world. Today, our world appears to be diverse, divided by language, religion and traditions. Yet, our heritage is more common and interconnected than we sometimes appreciate.' (Breeze et al., 2005: 12; my emphasis)
This statement emphasizes the common heritage of all the countries surrounding the Mediterranean, and that the frontiers of the Roman Empire have more than a specifically European relevance.

Since the Roman Empire incorporated peoples within a vast territory, it may be interpreted as an inclusive mechanism resulting from its policy of encouraging local self-government and urbanization throughout its territories (Breeze et al., 2005: 14-16). The FREWHS booklet suggests that the Roman frontiers were the 'membrane' through which Roman ideas and objects 'percolated' to reach the outside world beyond the Empire's limits (Breeze et al., 2005: 16; see Whittaker, 2004: 193). This is in keeping with a body of archaeological work that has used the distribution of artefacts on both sides of the imperial frontiers to assess the likely movement of people across them (e.g. Wells, 2013). The opportunities provided by the scientific analysis of human bones offer a potentially far more informed understanding of the movement of people across and within these frontiers (see Hingley, 2010; Nesbitt, 2016), although relatively little relevant research has been undertaken in the regions through which they passed.

To be included in the World Heritage List, sites must be rated as possessing outstanding universal value (UNESCO, 2016). The UNESCO World Heritage Centre sets out the methods UNESCO 'State Parties' must use to nominate potential World Heritage Sites and also the processes to be addressed before these can be inscribed by UNESCO in the World Heritage List. The process of nominating a World Heritage Site requires a State Party (or State Parties) to produce and submit to UNESCO a 'Statement of Outstanding Universal Value'. UNESCO's guidelines and regulations encourage the establishment of the identity of the 'Site' as 
exceptionally representative of a particular time and place.

The Statement of Outstanding Universal Values for the Frontiers of the Roman Empire and its Component Parts (SOUV) was produced as part of the FREWHS initiative and made available online by the UK's Department of Media and Culture (DCMS, 2011). ${ }^{4}$ The draft SOUV for the FREWHS drew on the earlier outputs of the initiative but rephrased the cultural relevance of the Roman frontiers in a manner that reflects the progress of the move for inscription. This document includes a fourpage synthesis which observes that:

'The FRE [Frontiers of the Roman Empire] as a whole has an extraordinarily high cultural value. It was the border of one of the most extensive civilizations in human history, which has continued to affect the western world and its peoples till today. It had an important effect on urbanisation and the spread of cultures among remote regions. The scope and extent of the frontier reflects the unifying impact of the Roman Empire on the wider Mediterranean world, an impact that persisted long after the empire had collapsed, while the frontiers are the largest single monument to the Roman civilization.' (DCMS, 2011; 2, my emphasis)

This SOUV follows UNESCO's template by outlining the importance of the FREWHS and supports this by providing evidence for three of the ten universal criteria that UNESCO requires in order to assess a monument or landscape for World Heritage Site status (UNESCO, 2016). Two of these criteria emphasize integration

\footnotetext{
4 This thirteen-page document was not finally submitted to UNESCO as part of the nomination process, although it provides an interesting set of observations. To date, the nominated sections of the FREWHS have produced their own independent SOUVs, which are available at the UNESCO World Heritage Centre. An earlier version of the SOUV was published by Breeze and Young (2008).
}

and the movement of people by commenting that:

\section{'Criterion iii}

The Roman frontier is the largest monument of the Roman Empire, one of the world's greatest preindustrial empires. The physical remains of Limes, forts, watchtowers, settlements and the hinterland dependent upon the frontier reflect the complexities of Roman culture but also its unifying factors across Europe and the Mediterranean world.

Unlike the Roman monuments already inscribed, the FRE's constructions are evidence from the edges of the Empires and reflect the adoption of Roman culture by its subject peoples. The frontier was not an impregnable barrier: rather it controlled and allowed the movement of peoples within the military units, amongst civilians and merchants, thus allowing Roman culture to be transmitted around the region and for it to absorb influences from outside its borders.

\section{Criterion iv}

The Frontier reflects the power and might of the Roman Empire and the spread of classical culture and Romanisation which shaped much of the subsequent development of Europe.' (DCMS, 2011; my emphasis)

This document emphasizes the idea of the unifying impact of the Roman Empire on its subject populations in the frontier regions, the movement of peoples and cultures across borders, and, on two occasions, the European and 'Western' inheritance of Rome's example. It also directly reflects the EU's policies of integration and free movement by emphasizing the former role of the Roman frontiers in spreading Roman culture, and in both controlling and allowing the movement of people.

A series of publications has been produced to communicate the particular characteristics of various regional sections of the 


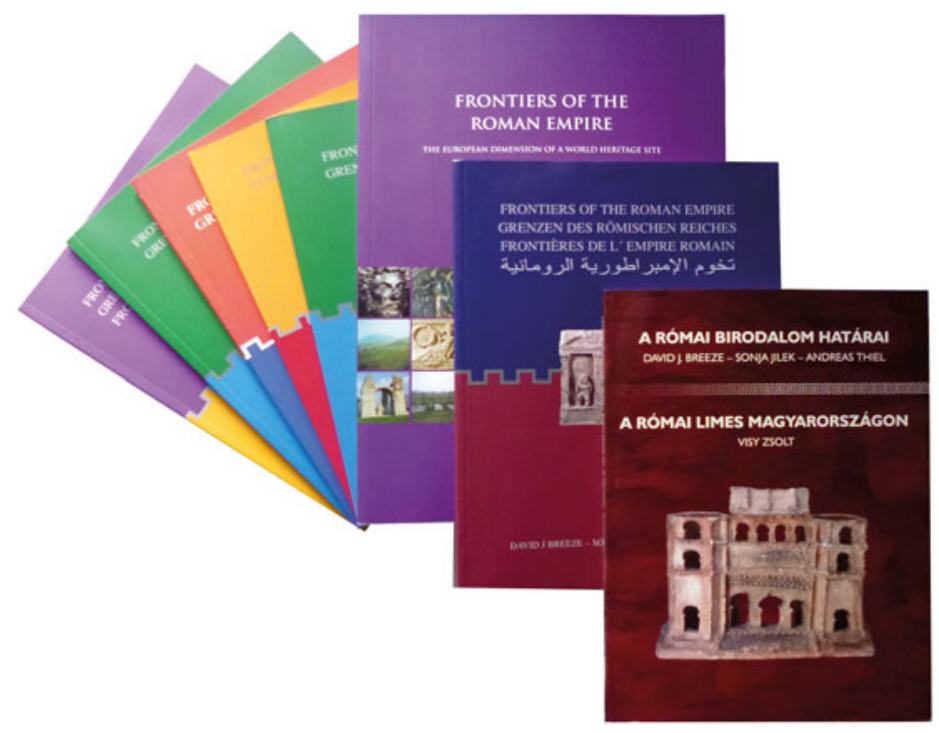

Figure 2. An assortment of publications derived from the Frontiers of the Roman Empire World Heritage Site initiative. Reproduced by permission of David Breeze.

FREWHS (Figure 2; these include Breeze et al., 2008; Zsolt, 2008; Jilek et al., 2011; Mattingly et al., 2013). These document the ways that the physical character of the Roman frontiers varied according to local topography and the character of the societies encountered by the Roman administration in different parts of the Empire, ${ }^{5}$ while also communicating the unified nature of the Roman frontiers as a whole. A directly co-operative agenda is outlined in all these publications, emphasizing the need for coordination but also for each State Party to follow its own approach in terms of understanding, protecting, managing, presenting, and interpreting its monuments (Breeze et al., 2005: 14-16). The FREWHS initiative has also created a separate body of literature focused on regional heritage practice, marketing, and

\footnotetext{
5 The volume on North Africa, for example, stresses the variability of the populations living in the frontier zone and emphasizes the importance of studying the 'indigenous peoples', reflecting the colonial context of much of the archaeological research undertaken across this region (Mattingly et al., 2013: 48).
}

interpretation to encourage people to visit and explore the archaeological remains (e.g. Breeze \& Jilek, 2008; Hingley, 2012: 301-05; Mills, 2013; Stone \& Brough, 2014; Brough, 2015).

The progress of the FREWH initiative appears currently to suggest that a unified monument will be created for the European sections, perhaps by 2020 (John Scott, pers. comm.). Those leading the FREWHS initiative have communicated the transnational values of the monument to a range of people throughout Europe and the Mediterranean world, although currently it appears likely that political, military, and cultural factors will prevent the realization of the inscription of Roman frontier works in North Africa and the Middle East. For people living across much of the southern and eastern Mediterranean, Roman frontier monuments may, indeed, represent a physical reminder of former colonial (and current economic and political) domination (Mattingly, 2011: 69). Some of the Roman frontier remains in Tunisia have been included in a Tentative 
List, although, in the current military and political context, it is easy to understand why relatively little progress has been made in nominating other parts across North Africa and the Middle East (Brough \& Scott, 2014: 118; Brough, 2015).

The nature of the archaeological evidence also influences the process of the inscription; it is much simpler to define the linear frontier works that make up much of the northern frontiers than the multiple fortified cities that defined the Empire's limits across much of the southern and eastern Mediterranean (David Breeze, pers. comm.). The success of the FREWHS initiative, however, also directly reflects the European focus of Roman Frontier Studies and the European claim to the inheritance of the cultural legacy of imperial Rome (Mattingly et al., 2013: 44-47; Brough 2015: 934).

\section{Bordering, Migration, AND the Values of Roman Frontiers}

Recent writings in the cross-disciplinary field of border studies have focused on migration and bordering in the contemporary world (for archaeological responses, see Hingley \& Hartis, 2011; Gardner, in press). This prolific body of research has developed in response to changing international strategies for controlling migration (see Kolossov, 2005; Rumford, 2006). It grew out of work undertaken during the later twentieth century but has been transformed because of pressures resulting from '9/11' and the 'War on Terror' (Wilson \& Donnan, 2012: 2-3). James Sidaway (2015: 216) has recently observed that 'Dozens (or probably hundreds) of books and hundreds (or probably thousands) of papers would need to be referenced to begin to do justice to border-studies'. Indeed, this cross-disciplinary field has expanded to the extent that it no longer has a single disciplinary agenda (Chris Rumford, pers. comm.). Border studies are characterized, however, by works that address the theories and practices of contemporary bordering (see Rumford, 2006; Wilson \& Donnan, 2012; Luath Bacas \& Kavanagh, 2013; Richardson, 2013; Jansen et al., 2015). Much of the output has paid critical attention to the ethics of bordering in the contemporary world, with a particular focus on the border policies of the EU. Other accounts of borders have emphasized the transformative and creative potential of such spaces as mechanisms of connectivity and encounter (e.g. Juffer, 2006; Hingley, 2010: 240; Parry, 2010; Hingley \& Hartis, 2011: 82-83; Cooper \& Rumford, 2013: 107); this may partly serve to counter the creation of increasingly impermeable boundaries.

The EU has been seeking to deal with large-scale migration across its borders during the past decades in a pragmatic and ethical manner. The scale of the problem at the EU's boundaries, and, increasingly, the crisis emerging at certain national boundaries within the EU, has, however, resulted in stringent critiques of EU policy and practice (e.g. Bialasiewicz, 2012; Carr, 2012; Jansen et al., 2015). Research has focused on the need to provide more detailed theoretical enquiries and ethical assessments of the 'amazing sophistication and complexity' of bordering practices that characterize the EU's borders (Bialasiewicz, 2012: 843-44). There is much emphasis on the ethics and power-relations behind contemporary borders and the importance of assessing the borders, and the question of the frontiers of pre-modern societies has been raised (Jansen et al., 2015: xvi). It has even been suggested that the EU's border policies and practices draw deeply on the example of the Roman frontiers (Hingley, 2015a: 62).

While conceptions of borders and mobilities in the contemporary world have 
become more complex, accounts of Roman frontiers have moved away from the nineteenth and early twentieth century imperial conception that they served as structures that separated 'civilisation' from 'barbarism' (Whittaker, 2004). New approaches explore the idea that Roman frontiers constituted more inclusive and transformative landscapes (Hingley, 2012: 311-21). A focus on the peopling of the Roman frontiers has addressed the multiple locations across the Roman Empire and beyond from which these populations originated and the ways that frontier lands acted to connect people and transform their identities (ibid.: 333-34). This draws on archaeological evidence for the ways of life of the communities living on the Roman frontiers, including auxiliary soldiers who were recruited from across the Empire (Breeze, 2011: 34-9). The encouragement of international tourism exploits the character of the Roman communities that once inhabited these frontier regions (Mills, 2013: 12). To entice people to visit the places that make up the Roman frontiers, strategies for tourism and interpretation focus primarily on the messages of mobility and inclusion long promoted by the EU.

Such a strategy helps to communicate the living relevance of these ancient works (Hingley, 2012: 1-8). Powerful and inclusive messages are generated for visitors to the regions with impressive physical remains of Roman frontier works, given that World Heritage can function as a tourism advertising strategy (see Long \& Labadi, 2010: 7). Income from visitors and tourists is vital for local communities in some of the European sections of the Roman frontier. Before the recent military and political difficulties, tourism also acted as a crucially important source of income for communities living close to the wellknown Classical monuments of the southern and eastern Mediterranean regions (Mattingly, 2011: 70-1; Lafrenz Samuels
\& Totten, 2012: 22-3; Mattingly et al., 2013: 92-93).

Re-enactment has been used for decades to draw the public to Roman heritage attractions and is popular along the European sections of the Frontiers of the Roman Empire (Figure 3; Appleby, 2005; Bishop, 2013). Living history events, artistic works, and digital media have come to the forefront of policy for the European sections of the Roman frontiers as a result of the emphasis on bringing these monuments to life to encourage tourism (see Breeze \& Jilek, 2008; Mills, 2013). For example, Jilek and colleagues observe that in Austria and Germany:

'Municipalities, museums and Roman societies along the Limes organise Roman events as special attractions, mainly for families ... To move outside their own exhibition spaces means to directly address the visitors, giving them a better chance to enter into the living conditions to the Roman world. Re-enactment groups ... demonstrate how Roman soldiers and civilians lived.' (Jilek et al., 2011: 86)

Roman buildings have also been reconstructed to help inform visitors to the monuments (Figure 4; see also Flügel \& Obmann, 2013).

These cultural and heritage practices are perhaps most fully developed on Hadrian's Wall, where the initiative 'Illuminating Hadrian's Wall' in 2009 brought people together from across the UK and beyond to light beacons along the entire length of the monument at sunset (Hingley, 2012: $6-7,332)$. Works of border studies seldom consider pre-modern borders and frontiers, but in Anthony Cooper and Chris Rumford's 'Monumentalising the Border: Bordering through Connectivity', the authors mention the 'Connecting Lights' event held on Hadrian's Wall during the Summer Olympics of 2012 which linked 


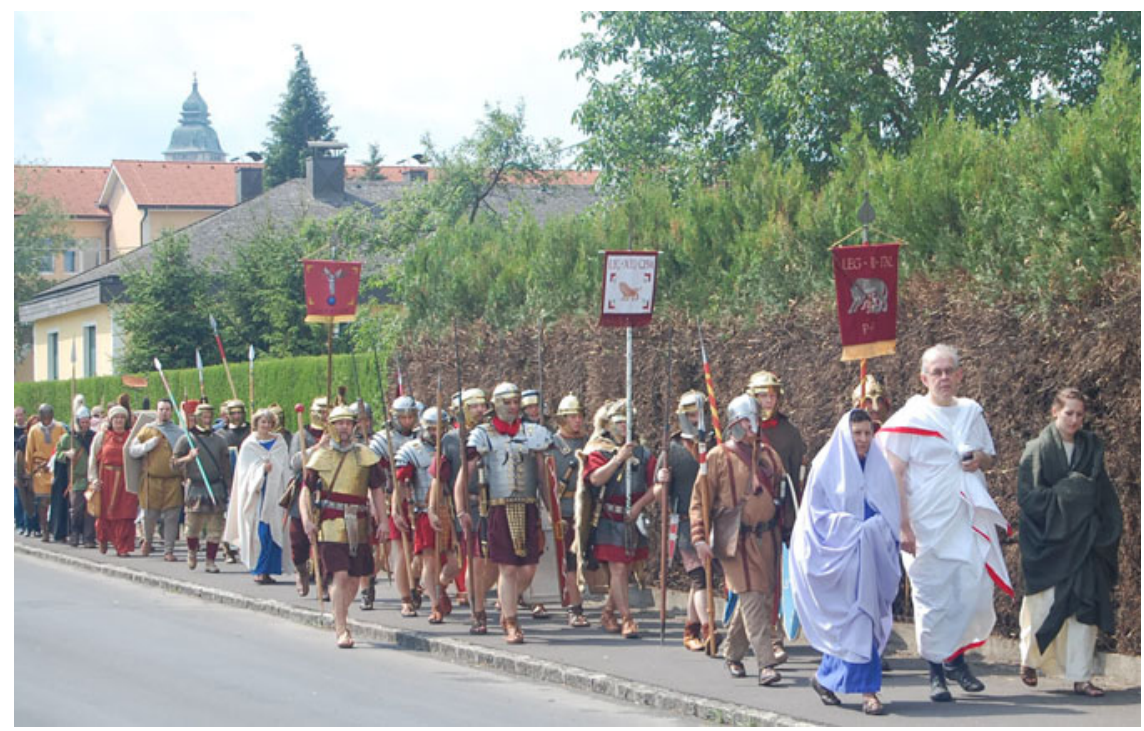

Figure 3. A re-enactment Roman event in the town of Enns, Austria. Reproduced by permission of Eva Kuttner.

the $117 \mathrm{~km}$ of this monument with a line of pulsating two-metre diameter lighted balloons, intended to encourage people to view the Wall as a bridge rather than a barrier (Cooper \& Rumford 2013: 107, 120). Cooper and Rumford (2013: 114) also argue that "border monuments and public art situated on or near borders are increasingly designed to celebrate cultural encounters and/or the ability of borders to connect as well as divide'. Festivals have publicized Hadrian's Wall as an inclusive

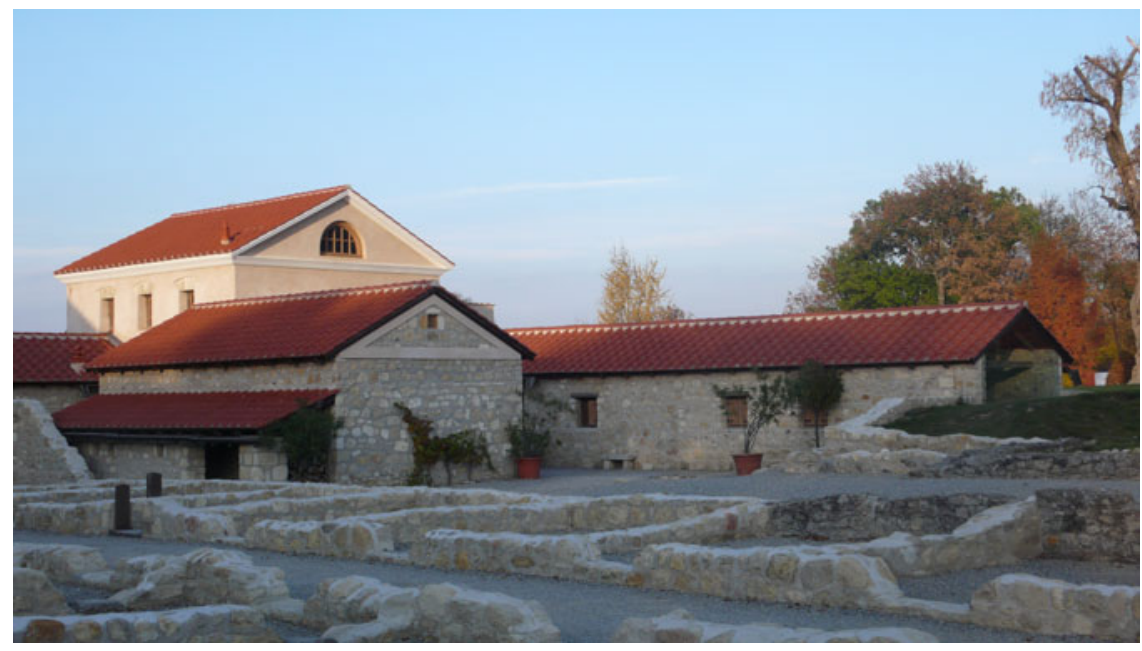

Figure 4. The Roman civil town at Carnuntum, Austria, showing buildings that have been reconstructed and displayed for the public. Reproduced by permission of Sonja Jilek. 
heritage landscape that brings people together from across the world. These are aspects of a sustained variety of activities that aim to promote the monument and its constituent parts as exciting places to visit (Hingley, 2012: 333-35).

Hadrian's Wall fits very well within Cooper and Rumford's definition of 'postnational borders' as 'mechanisms of connectivity and encounter' rather than as markers of national or colonial division. The extension of World Heritage Site status to the other European sections of the Frontiers of the Roman Empire is pioneering a transnational approach to celebrate cultural encounter and the connective aspects of borders in both the ancient past and the contemporary age. These activities call on a broader range of values derived from the Roman Empire than those of colonialism and imperialism (see Lafrenz Samules \& Totten, 2012: 23), including ideas of mobility and cultural integration. Breeze and colleagues, in a study of the Roman frontiers in Slovakia, have noted that:

'The very commonality of Roman frontiers demands that they are treated as a single monument. Roman frontiers are the joy of the aficionado of cultural tourism-here is one great cultural route running right around the Roman empire ..., offering not just different sites but a wide range of landscapes and scenery.' (Breeze et al., 2008: 46)

Tourism is encouraged through this work although much of the emphasis across Europe appears to be focused on informing people about the importance of managing and maintaining these resources (see Jilek et al., 2011: 86-87).

The idea of the Roman frontiers as contexts for cultural encounter appears to have been developed most fully with regard to Hadrian's Wall. While the potential role of the Roman frontiers in connecting people and transforming identities is addressed in the public realm, comparatively little has been done to explore issues of bordering and mobilities from more critical perspectives (Hingley, 2012: 319-20).

The 'Frontiers Gallery' at Tullie House Museum (Carlisle, England) brings Roman frontiers into a direct relationship with the present by addressing 'the concept of resonances with the modern world and in particular the perspectives of people today for whom the experience of the frontier is part of their daily life and worldview' (Mills et al., 2013: 184). This gallery adopts the 'narrative of the Roman frontier' to 'act as a metaphor through which to explore significant contemporary issues' (Ibid.: 185). The intention here is to challenge the visitor to think about the moral and ethical issues that affect us all in the context of UNESCO's wider agenda of promoting peaceful coexistence and partnership between nations of the world through respect, understanding, toleration, and co-operation. One feature involves the projection of still scenes of disrupted lives on modern borders onto a screen in the shape of the map covered by the area of the Hadrian's Wall World Heritage Site (Figure 5). This includes scenes from the lives of migrant peoples who have become caught in international borders, such as the increasingly well-defined borders of the EU.

Visitors are asked to write their comments on pieces of paper and attach them to a board for others to read. Their messages demonstrate that members of the public visiting the museum feel considerable discomfort when thinking about bordering in the past and, particularly, in the present. The pursuit of ethical and political considerations may indeed form one of the prime public values that may be developed through the display and interpretation of the Roman past, allowing the complexities of the past and present to be 


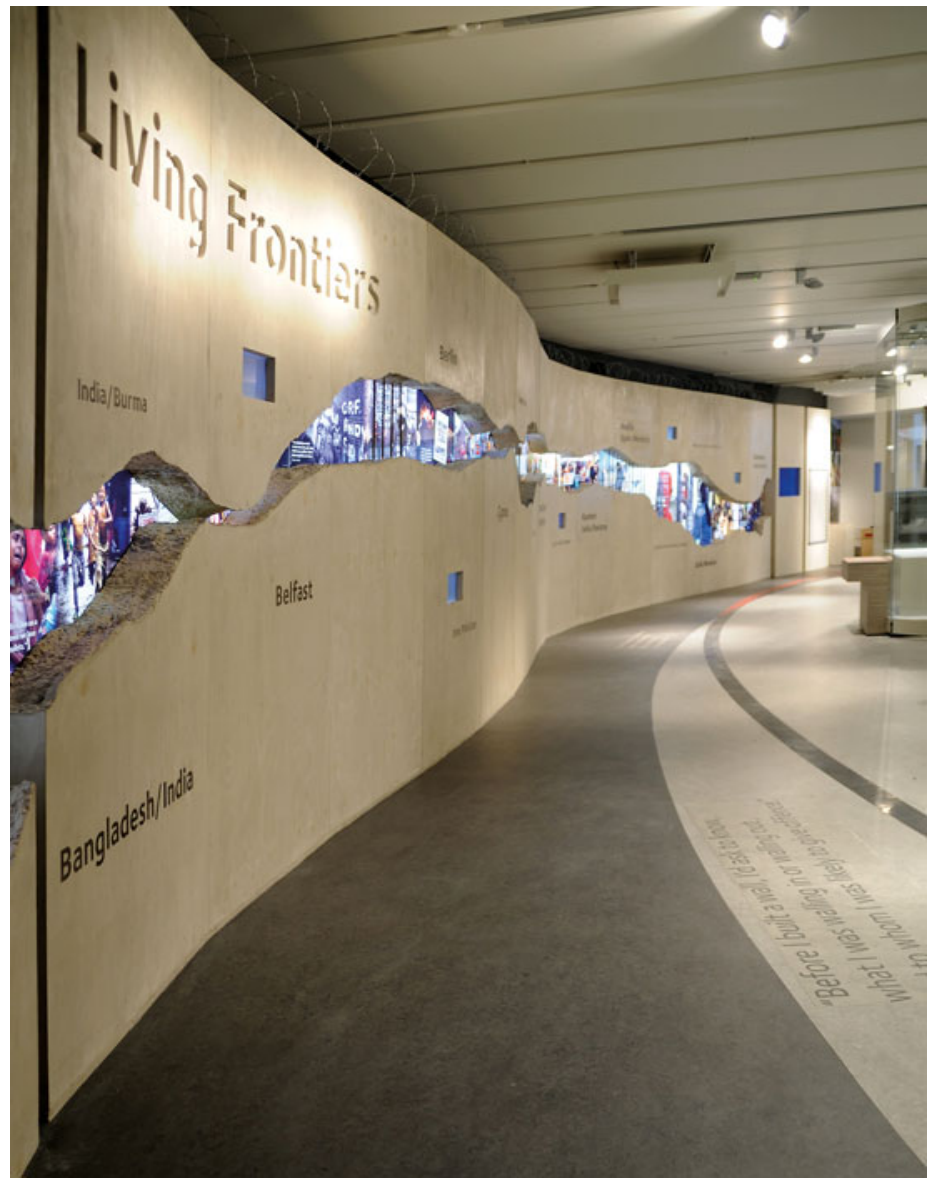

Figure 5. The Roman Frontier Gallery, The Living Wall, Tullie House Museum, Carlisle, England. Reproduced by permission of Tullie House Museum, Carlisle, England.

addressed in the public arena (see Labadi, 2010: 81). This may be seen as a negative message by many who seek to publicize the Roman frontiers for visitors, although it should be possible to adopt a more nuanced perspective that emphasizes the variable characters of frontiers and borders in both the past and the present.

\section{Conclusion}

Attempts to manage the movement of people across the EU's borders have been deeply challenged by the political troubles that have transformed the lands to the south and east of the Mediterranean over the past decade, leading to sustained scholarly and public criticism of the EU's policies and practices on its borders. With the shock of the UK's vote to leave the EU in mind, we seem to be faced with a stark choice: either to seek to maintain an international policy that attempts to manage migration across borders in an increasingly unstable world, or to progressively close borders and convert them into monumentalized frontiers. The latter approach would lead to an increasing fragmentation of the international community at a time when co-operation is increasingly vital. 
Historical studies of borders and frontiers tend to indicate that these works seldom work for any sustained period (Foster, 2013: 3-4; Chaichian 2014). The Roman frontiers are an exception in this respect, since they only collapsed after several centuries. Perhaps their lengthy history of operation was partly due to their flexibility in enabling migration across their lines. Emphasizing the complexity of border cultures and the roles of borders and frontiers in both the past and the present helps to communicate the normality of migration throughout human history and the creative character of encounter, while the central role of Classical Rome in European concepts of origin emphasizes the academic and public potency of the tangible ruins of Roman frontier culture.

Although the promotion of the ancient frontier works of a militarized dictatorship may appear to be a problematic context for communicating an idea of common heritage (Hingley, 2015a), the co-operation of archaeologists and heritage managers in the FREWHS initiative has championed a World Heritage Site with major public appeal. The Roman frontiers are likely to continue to form an increasingly popular series of heritage landscapes and draw in visitors from far afield, from Europe at least. The potential of this heritage asset also partly lies in researching and communicating the complex ethical context of the contemporary borders across the globe as well as the intricate ways in which the past and the present are entangled (see Hayes \& Cipolla, 2015). Such an analysis may address the disconnections as well as the connections between past and present (see Whittaker, 2004: 193; Hingley, 2015b). The contemplation of these Roman frontier works is of value to scholars, visitors, readers of accessible books on the subject, and consumers of digital heritage regarding the complexity and temporal depth of the issues that affect the world in which we live. Thinking about these monuments also highlights themes that need to be addressed if we are to imagine the possibility of better futures. It remains the task of those who study ancient frontiers to consider migration and bordering in deeper terms and explore how the increasing normalization of the argument for the stringent treatment of migrants has emerged (see Jansen et al., 2015).

\section{ACKNOWLEDGEMENTs}

This research developed from the 'Tales of the Frontier' project (supported by the Arts and Humanities Research Council [2007-2014], Grant Number AHE510345/ 1). It also grew from discussions arising from the 'Life of the Frontier' initiative, funded by the Institute of Advanced Studies at Durham University (2011-2012). I particularly wish to acknowledge the assistance of a number of colleagues, particularly Professor David Breeze, Dr Chiara Bonacchi, Professor Emmanuel BrunetJailly, Dr Andrew Burridge, Dr Andy Gardner, Professor Stephen Harrison, Dr Sonja Jilek, Dr Sofia Labadi, Dr Dan Lawrence, Andrew Mackay, Dr Nigel Mills, Professor Chris Rumford, John Scott, Christina Unwin, Dr Robert Witcher, and the editors of the European Journal of Archaeology.

\section{REFERENCES}

Appleby, G.A. 2005. Crossing the Rubicon: Fact or Fiction in Roman Re-enactment. Public Archaeology, 4: 257-65.

Askew, M. 2010. The Magic List of Global Status: UNESCO, World Heritage and the Agenda of States. In: S. Labadi \& C. Long, eds. Heritage and Globalisation. London: Routledge, pp. 19-44. 
Bialasiewicz, L. 2012. Off-shoring and Outsourcing the Borders of EUrope: Libya and EU Border Work in the Mediterranean. Geopolitics, 17: 843-66.

Biebuych, W. \& Rumford, C. 2012. Many Europes: Rethinking Multiplicity. European Journal of Social Theory, 15: 3-20.

Birley, A.R. 2002. Fifty Years of Roman Frontier Studies. In: P. Freeman, J. Bennett, Z.T. Fiema \& B. Hoffmann, eds. Limes XVIII: Proceedings of the XVIIIth International Congress of Roman Frontier Studies, Held in Amman, September 2000. Oxford: Archaeopress: pp. 1-11.

Bishop, M. 2013. Re-enactment and Living History-Issues about Authenticity. In: N. Mills, ed. Presenting the Romans: Interpreting the Frontiers of the Roman Empire World Heritage Site. Woodbridge: Boydell Press, pp. 23-30.

Bloemers, T. 1989. Acculturation in the Rhine/Meuse Basin in the Roman Period. In: J. Barrett, A. Fitzpatrick \& L. Macinnes, eds. Barbarians and Romans in North-West Europe (BAR International Series 471). Oxford: British Archaeological Reports, pp. 175-97.

Breeze, D.J. 2008. Research on Roman Frontiers. In: D.J. Breeze \& S. Jilek, eds. Frontiers of the Roman Empire: The European Dimension of a World Heritage Site. Edinburgh: Historic Scotland, pp. 57-59.

Breeze, D.J. 2011. The Frontiers of Imperial Rome. Barnsley: Pen \& Sword.

Breeze, D.J. \& Jilek, S. eds. 2008. Frontiers of the Roman Empire: The European Dimension of a World Heritage Site. Edinburgh: Historic Scotland.

Breeze, D.J. \& Young, C. 2008. Frontiers of the Roman Empire World Heritage Site Summary Notification Statement. In: D.J. Breeze \& S. Jilek, eds. Frontiers of the Roman Empire: The European Dimension of a World Heritage Site. Edinburgh: Historic Scotland, pp. 29-36.

Breeze, D.J., Jilek, S. \& Thiel, A. 2005. Frontiers of the Roman Empire. Edinburgh \& Esslingen: Historic Scotland/Deutsche Limeskommission.

Breeze, D.J., Jilek, S. \& Thiel, A. 2008. Frontiers of the Roman Empire/Grenzen des Römischen Reiches/Hranice Rimskej Riše: Slovakia/Slowakei/Slovensko. Edinburgh, Esslingen, Vienna \& Nitra: Historic
Scotland/Deutsche Limeskommission/ Archeologickÿ ústav SAV.

Brough, D. 2015. Factors Influencing the Future Development of the Frontiers of the Roman Empire World Heritage Site. In: L. Vagalinski \& N. Sharankov, eds. Limes XXII: Proceedings of the 22nd International Congress of Roman Frontier Studies. Sofia: National Archaeological Institute with Museum of the Bulgarian Academy of Science, pp. 933-40.

Brough, D. \& Scott, J. 2014. The Frontiers of the Roman Empire World Heritage Site. In: P. Stone \& D. Brough, eds. Managing, Using, and Interpreting Hadrian's Wall as World Heritage. New York: Springer, pp. 115-25.

Carr, M. 2012. Fortress Europe: Dispatches from a Gated Continent. London: Hurst.

Chaichian, M.A. 2014. Empires and Walls: Globalisation, Migration, and Colonial Domination. Chicago (IL): Haymarket.

Cooper, A. \& Rumford, C. 2013. Monumentalising the Border: Bordering through Connectivity. Mobilities, 8: 107-24.

DCMS 2011. Statement of Outstanding Universal Value for the Frontiers of the Roman Empire and its Component Parts (WHS FRE) (C430). London: DCMS [online] [accessed 27 October 2016]. Available at $<\mathrm{http} / / /$ old.culture.gov.uk/what_ we_do/historic_environment/9095.aspx>

Eckardt, H. ed. 2010. Roman Diasporas: Archaeological Approaches to Mobility and Diversity in the Roman Empire (Journal of Roman Archaeology Supplementary Series 78). Portsmouth (RI): Journal of Roman Archaeology.

Eckardt, H. \& Müldner, G. 2016. Mobility, Migration, and Diaspora in Roman Britain. In: M. Millett, L. Revell \& A. Moore, eds. The Oxford Handbook of Roman Britain. Oxford: Oxford University Press, pp. 203-23.

Eckardt, H., Müldner, G. \& Lewis, M. 2014. People on the Move in Roman Britain. World Archaeology, 46: 534-50.

Eder, K. 2006. Europe's Borders: The Narrative Construction of the Boundaries of Europe. European Journal of Social Theory, 9: 255-71.

European Commission, 1957. The Treaty of Rome. [online] [accessed 26 May 2016]. Available at <http://eu-ropa.eu/eu-law/ decision-making/treaties/index_en.htm> 
European Union, 2016. European Union: Enlargement [online] [accessed 1 November 2016]. Available at <http://europa.eu/ european-union/topics/enlargement_en>

Figel, J. 2008. Foreword. In: D.J. Breeze \& S. Jilek, eds. Frontiers of the Roman Empire: The European Dimension of a World Heritage Site. Edinburgh: Historic Scotland, p. 1.

Flügel, C. \& Obmann, J. eds. 2013. Römische Webrbauten: Befund und Rekonstruktion. Munich: Volk Verlag.

Foster, R. 2013. Introduction: Between These Two Kinds of Death. Global Discourse, 3: 3-11.

Gambash, G. 2015. Rome and Provincial Resistance. Abingdon: Routledge.

Gardner, A. in press. Brexit, Boundaries, and Imperial Identities: A Comparative View. Journal of Social Archaeology.

Geary, P.J. 2002. The Myth of Nations: The Medieval Origins of Europe. Oxford: Princeton University Press.

González Sánchez, S. \& Guglielmi, A. eds. in press. 'Romans' and 'Barbarians' Beyond the Frontier: Archaeology, Ideology and Identities in the North. Oxford: Oxbow.

Graves-Brown, P., Jones, S. \& Gamble, C. eds. 1996. Cultural Identity and Archaeology: The Construction of European Communities. London: Routledge.

Haffner, A. \& von Schnurbein, S. 1996. Kelten, Germanen, Römer im Mittelgebirgsraum zwischen Luxemburg und Thüringen. Arcäologisches Nachrichtenblatt, 1: 70-77.

Hannam, K., Sheller, M. \& Urry, J. 2006. Editorial: Mobilities, Immobilities and Moorings. Mobilities, 1: 1-22.

Hayes, K.H. \& Cipolla, N.C. 2015. Introduction: Re-imagining Colonial Pasts, Influencing Colonial Futures. In: N.C. Cipolla \& K.H. Hayes, eds. Rethinking Colonialism: Comparative Archaeological Approaches. Gainesville (FL): University Press of Florida, pp. 1-13.

Herzfeld, M. 2008. Mere Symbols. Anthropologica, 50: 141-55.

Hingley, R. 2001. Images of Rome: Perceptions of Ancient Rome in Europe and in the United States in the Modern Age (Journal of Roman Archaeology Supplementary Series 44). Portsmouth (RI): Journal of Roman Archaeology.

Hingley, R. 2005. Globalizing Roman Culture: Unity, Diversity and Empire. London: Routledge.
Hingley, R. 2010. Tales of the Frontier: Diasporas on Hadrian's Wall. In: H. Eckardt, ed. Roman Diasporas: Archaeological Approaches to Mobility and Diversity in the Roman Empire. Portsmouth (RI): Journal of Roman Archaeology, pp. 227-43.

Hingley, R. 2012. Hadrian's Wall: A Life. Oxford: Oxford University Press.

Hingley, R. 2015a. The Frontiers of the Roman Empire World Heritage Site and Transnational Heritage. In: P.F. Biehl, D. Cromer, C. Prescott \& H. Soderland, eds. Identity and Heritage: Contemporary Challenges in a Globalized World. New York: Springer, pp. 55-64.

Hingley, R. 2015b. Post-colonial and Global Rome: The Genealogy of Empire. In: M. Pitts \& J.M. Versluys, eds. Globalisation and the Roman World: World History, Connectivity and Material Culture. Cambridge: Cambridge University Press, pp. 32-46.

Hingley, R. in press. Introduction: Imperial limits and the Crossing of Frontiers. In: S. González Sánchez \& A. Guglielmi, eds. 'Romans' and 'Barbarians' Beyond the Frontier: Archaeology, Ideology and Identities in the North. Oxford: Oxbow.

Hingley, R. \& Hartis, R. 2011. Contextualizing Hadrian's Wall as 'Debatable Lands'. In: O. Hekster \& T. Kaizer, eds. Frontiers in the Roman World: Proceedings of the Ninth Workshop of the International Network Impact of Empire. Leiden: Brill, pp. 79-96.

Hsu, R. 2010. Ethnic Europe: Mobility, Identity, and Conflict in a Globalized World. Stanford (CA): Stanford University Press.

Isaac, B. 2000. The Limits of Empire: The Roman Army in the East, revised edition. Oxford: Oxford University Press.

Jankovic, M.A., Mihajlovic, V.D. \& Babic, S. eds. 2014. The Edges of the Roman World. Newcastle upon Tyne: Cambridge Scholars Publishing.

Jansen, Y., Celibates, R. \& de Bloois, J. 2015. Introduction. In: Y. Jansen, R. Celibates \& J. de Bloois, eds. The Irregularization of Migration in Contemporary Europe: Detention, Deportation, Drowning. London \& New York: Rowman \& Littlefield, pp. ix-xxiv. 
Jilek, S., Kuttner, E. \& Schwarcz, A. 2011. Frontiers of the Roman Empire: The Danube Limes in Austria. Vienna: Austrian Institute for Historical Research.

Juffer, J. ed. 2006. The Last Frontier: The Contemporary Configuration of the U.S.Mexico Border (South Atlantic Quarterly 105(4)). Durham (NC): Duke University Press.

Klose, G. \& Nünnerich-Asmus, A. eds. 2005. Grenzen des Römischen Imperiums. Mainz am Rhein: Phillip von Zabern.

Kolossov, V. 2005. Border Studies: Changing Perspectives and Theoretical Approaches. Geopolitics, 10: 606-32.

Labadi, S. 2010. World Heritage: Authenticity and Post-Authenticity: International and National Perspectives. In: S. Labadi \& C. Long, eds. Heritage and Globalisation. London: Routledge, pp. 66-84.

Lafrenz Samuels, K. \& Totten, D.M. 2012. Roman Place-Making: From Archaeological Interpretation to Contemporary Heritage Contexts. In: D.M. Totten \& K. Lafrenz Samuels, eds. Making Roman Places, Past and Present: Papers Presented at the First Critical Roman Archaeology Conference held at Stanford University in March, 2008 (Journal of Roman Archaeology Supplementary Series 89). Portsmouth (RI): Journal of Roman Archaeology, pp. 11-32.

Long, C. \& Labadi, S. 2010. Introduction. In: S. Labadi \& C. Long, eds. Heritage and Globalisation. London: Routledge, pp. 1-16.

Luath Bacas, J. \& Kavanagh, W. 2013. Border Encounters: Asymmetry and Proximity at Europe's Frontiers. In: J. Luath Bacas \& W. Kavanagh, eds. Border Encounters: Asymmetry and Proximity at Europe's Frontiers. New York: Berghahn, pp. 1-23.

Martiniano, R., Caffell, A., Holst, M., Hunter-Mann, K. \& Müldner, G. 2016. Genomic Signals of Migration and Continuity in Britain before the AngloSaxons. Nature Communications, 7: 10326 doi: $10.1038 /$ ncomms10326.

Mattingly, D. 2011. Imperialism, Power and Identity: Experiencing the Roman Empire. Princeton (NJ) \& Oxford: Princeton University Press.

Mattingly, D., Rushworth, A., Sterry, M. \& Leitch, V. 2013. Frontiers of the Roman Empire/Grenzen des Römischen Reiches/ Frontières de l'Empire romain: The African
Froniers/Die Grenzen in Afrika/Les Frontières africaines. Edinburgh: Hussar.

Maxfield, V. \& Dobson, M. 1991. Roman Frontier Studies 1989. Exeter: University of Exeter Press.

Mills, N. ed. 2013. Presenting the Romans: Interpreting the Frontiers of the Roman Empire World Heritage Site. Woodbridge: Boydell Press.

Mills, N., Padley, T., Scott, J., Branczik, L. \& Adkins, G. 2013. Applying the Hadrian's Wall Interpretational Framework. In: N. Mills, ed. Presenting the Romans: Interpreting the Frontiers of the Roman Empire World Heritage Site. Woodbridge: Boydell Press, pp. 181-92.

Morley, N. 2010. The Roman Empire: Roots of Imperialism. New York: Pluto Books.

Moschek, W. 2011. Der Römische Limes. Eine Kultur- und Mentalitätsgeschichte. Munich: Speyer.

Nesbitt, C. 2016. Multiculturalism on Hadrian's Wall. In: M. Millett, L. Revell \& A. Moore, eds. The Oxford Handbook of Roman Britain. Oxford: Oxford University Press, 244-45.

Parry, W. 2010. Against the Wall: The Art of Resistance in Palestine. London: Pluto Press.

Redfern, R.C., Gröcke, D.R., Millard, A.R., Ridgeway, V., Johnson, L. \& Hefner, J.T. 2016. Going South of the River: A Multidisciplinary Analysis of Ancestry, Mobility and Diet in a Population from Roman Southwark, London. Journal of Archaeological Science, 74: 11-22.

Richardson, T. 2013. Borders and Mobilities: Introduction to the Special Issue. Mobilities, 8: 1-6.

Roymans, N. Heeren, S. \& De Clercq, W. eds. 2016. Social Dynamics in the Northwest Frontiers of the Late Roman Empire: Beyond Decline or Transformation. Amsterdam: Amsterdam University Press.

Rumford, C. 2006. Introduction: Theorizing Borders. European Journal of Social Theory, 9: $155-69$.

Sidaway, J. 2015. Mapping Border Studies: Book Review Essay. Geopolitics, 20: 21422.

Sommer, C.S. 2015. WHS FRE (Frontiers of the Roman Empire) - Running and Expanding the World Heritage Site. In: L. Vagalinski \& N. Sharankov, eds. Limes XXII: Proceedings of the 22nd International Congress of Roman Frontier Studies. Sofia: 
National Archaeological Institute with Museum Bulgarian Academy of Science, pp. 919-22.

Stone, P. \& Brough, D. eds. 2014. Managing, Using, and Interpreting Hadrian's Wall as World Heritage. New York: Springer.

Tolia-Kelly, D. 2010. Narrating the Postcolonial Landscape: Archaeologies of Race at Hadrian's Wall. Transactions of the Institute of British Geographers, NS 36: 71-88.

UNESCO 2016. UNESCO World Heritage List [online] [accessed 27 October 2016]. Available at: <http://whc.unesco.org>

van Dommelen, P. 2014. Moving On: Archaeological Perspectives on Mobility and Migration. World Archaeology, 46: 477-83.

Versluys, M.J. 2014. Understanding Objects in Motion: An Archaeological Dialogue on Romanization. Archaeological Dialogues, 21: 1-20.

Wells, P. ed. 2013. Rome beyond its Frontiers: Imports, Attitudes and Practices (Journal of Roman Archaeology Supplementary Series 94). Portsmouth (RI): Journal of Roman Archaeology.

Whittaker, C.R. 2004. Rome and its Frontiers: The Dynamics of Empire. London: Routledge.

Wilson, T.M. \& Donnan, H. 2012. Borders and Border Studies. In: T.M. Wilson \& H. Donnan, eds. A Companion to Border Studies. Chichester: Wiley-Blackwell, pp. 1-21.

Witcher, R. 2015. Globalisation and Roman Cultural Heritage. In: M. Pitts \& M.J.
Versluys, eds. Globalisation and the Roman World: World History, Connectivity and Material Culture. Cambridge: Cambridge University Press, pp. 198-222.

Zielonka, J. 2006. Europe as Empire: The Nature of the Enlarged European Union. Oxford: Oxford University Press.

Zsolt, V. 2008. A Római Limes Magyarországon. In: D.J. Breeze, S. Jilek \& A. Thiel, eds. A Római Birdalom Határai/Frontiers of the Roman Empire. Edinburgh, Esslingen and Pécs: Historic Scotland/Deutsche Limeskommission/Pécsi Tudományegyetem Régészeti Szeminárium, pp. 35-78.

\section{Biographical Note}

Richard Hingley is a Professor of Roman Archaeology at Durham University, UK. His research focuses upon Iron Age and Roman society and he has published a variety of books, including Roman Officers and English Gentlemen (2000), Globalizing Roman Culture (2005) and Hadrian's Wall: $A$ Life (2012). He is a member the World Heritage Site Management Panel for Hadrian's Wall.

Address: Department of Archaeology, Durham University, UK. [Email: richard. hingley@durham.ac.uk]

\section{Frontières et mobilités : les frontières de l'Empire romain et l'Europe}

L'article ci-dessus traite du site du patrimoine mondial que constituent les "Frontières de l'Empire romain " et cherche à introduire dans cette initiative certains concepts formulés dans des écrits récents sur la mobilité et la délimitation des frontières contemporaines dans le but d'étudier la possibilité de créer une collaboration plus étroite entre les deux domaines que sont l'étude des frontières actuelles et l'étude des frontières romaines. L'examen des rapports entre l'initiative sur les "Frontières de l'Empire romain" et les objectifs fondamentaux d'intégration et de dissolution des frontières de l'Union européenne nous mène à proposer une approche qui transcende les frontières intellectuelles entre l'étude du passé et celle du présent et de promouvoir les valeurs que représentent les frontières romaines comme moyen de réflexion sur les problèmes auxquels l'Europe se trouve confrontée aujourd'bui. Dans cet article nous examinons l'influence que les études sur les frontières romaines pourraient avoir dans ce débat en soulignant le rôle des frontières comme lieux de rencontre et de transformation. Translation by Madeleine Hummler

Mots-clés: frontières, rencontres, mobilité, Empire romain, Union européenne, patrimoine mondial 


\section{Grenzen und Mobilität: die Grenzen des römischen Reiches und Europa}

In diesem Artikel wird das Weltkulturerbe "Grenzen des Römischen Reiches" besprochen, und es wird versucht, einige Konzepte, die von neueren Veröffentlichungen über Mobilität und Begrenzungen in der heutigen Welt beeinflusst sind, in diese Initiative einzufübren; es wird auch versucht, eine engere Zusammenarbeit zwischen den wissenschaftlichen Feldern, die sich den modernen Grenzen und den römischen Grenzen widmen, zu fördern. Die Auswertung der Zusammenhänge zwischen dem Projekt "Grenzen des Römischen Reiches" und den grundsätzlichen Zielen der Integrierung und Abschaffung der Grenzen innerhalb der Europäischen Union fübrt zur Empfeblung, intellektuelle Grenzen zwischen dem Studium der Gegenwart und der Vergangenheit zu überschreiten, um den Wert der römischen Grenzen als Mittel einer Betrachtung der aktuellen Grenzproblemen Europas zu fördern. Die potenzielle Bedeutung der römischen Grenzen in dieser Debatte, vor allem ibre Rolle als Orte der Begegnung und des Wandels wird hier betont. Translation by Madeleine Hummler

Stichworte: Grenzen, Begrenzung, Begegnung, Mobilität, römisches Reich, Europäische Union, Welterbe 